\title{
Structural, functional and mutational analysis of the pfr gene encoding a ferritin from Helicobacter pylori
}

\author{
Stefan Bereswill, ${ }^{1}$ Uta Waidner, ${ }^{1}$ Stefan Odenbreit, ${ }^{2}$ Flavia Lichte, ${ }^{1}$ \\ Frank Fassbinder, ${ }^{1}$ Günter Bode ${ }^{3}$ and Manfred Kist ${ }^{1}$
}

Author for correspondence: Stefan Bereswill. Tel: +49761 2036539. Fax: + 497612036562 .
e-mail: bereswil@sun1.ukl.uni-freiburg.de

1 University of Freiburg, Institute of Medical Microbiology and Hygiene, Department of Microbiology and Hygiene, Hermann-Herder-Str. 11, D-79104 Freiburg, Germany

2 Max-von-PettenkoferInstitute of Hygiene and Medical Microbiology, Department of Bacteriology, Pettenkoferstr. 9a, D80336 Munich, Germany

3 University of Ulm, Department of Internal Medicine I, Robert KochStr. 8, D-89081 Ulm, Germany

\begin{abstract}
The function of the pfr gene encoding the ferritin from Helicobacter pylori was investigated using the Fur titration assay (FURTA) in Escherichia coli, and by characterization of a pfr-deficient mutant strain of $\boldsymbol{H}$. pylori. Nucleotide sequence analysis revealed that the pfr region is conserved among strains ( $>95 \%$ nucleotide identity). Two transcriptional start sites, at least one of them preceded by a $\sigma^{70}$-dependent promoter, were identified. Provision of the $\boldsymbol{H}$. pylori pfr gene on a multicopy plasmid resulted in reversal of the Fur-mediated repression of the fhuF gene in $E$. coli, thus enabling the use of the FURTA for cloning of the ferritin gene. Inactivation of the pfr gene, either by insertion of a resistance cassette or by deletion of the up- and downstream segments, abolished this function. Immunoblot analysis with a Pfr-specific antiserum detected the Pfr protein in $H$. pylori and in E. coli carrying the pfr gene on a plasmid. Pfr-deficient mutants of $\boldsymbol{H}$. pylori were generated by markerexchange mutagenesis. These were more susceptible than the parental strain to killing by various metal ions including iron, copper and manganese, whereas conditions of oxidative stress or iron deprivation were not discriminative. Analysis by element-specific electron microscopy revealed that growth of $\boldsymbol{H}$. pylori in the presence of iron induces the formation of two kinds of cytoplasmic aggregates: large vacuole-like bodies and smaller granules containing iron in association with oxygen or phosphorus. Neither of these structures was detected in the pfr-deficient mutant strain. Furthermore, the ferritin accumulated under iron overload and the pfr-deficient mutant strains lacked expression of a $12 \mathrm{kDa}$ protein which was negatively regulated by iron in the parental strain. The results indicate that the nonhaem-iron ferritin is involved in the formation of iron-containing subcellular structures and contributes to metal resistance of $\boldsymbol{H}$. pylori. Further evidence for an interaction of ferritin with iron-dependent regulation mechanisms is provided.
\end{abstract}

Keywords: Helicobacter pylori, prokaryotic ferritin, metal resistance, iron sequestration

\section{INTRODUCTION}

The Gram-negative, spiral-shaped, microaerophilic bacterium Helicobacter pylori is the causative agent of various diseases of the upper gastrointestinal tract, such

Abbreviations: FURTA, Fur titration assay; TEM, transmission electron microscopy.

The EMBL accession numbers for the sequences of the pfr regions of H. pylori strains $\mathrm{P} 1$ and $\mathrm{G} 27$ are $\mathrm{Y} 16068$ and AJ006035, respectively. as chronic gastritis and peptic ulceration (Buck, 1990; Lee $e t$ al., 1993). This pathogen is furthermore believed to trigger the development of gastric adenocarcinoma and MALT lymphoma (Asaka et al., 1994; Forman, 1996). The bacteria colonize under the mucous layer of the stomach, in close contact with the epithelial cells. $H$. pylori is highly adapted to this specific environment, as it has developed strategies to acquire iron from hostborne sources including lactoferrin (Dhaenens et al., 1997), transferrin (Velayudhan et al., 1997), and haemin 
(Husson et al., 1993; Worst et al., 1995, 1996). Genes which are homologous to uptake systems for ferrous iron $(f e o)$, ferric iron $(\mathrm{ceu})$, and iron-citrate complexes $(f e c)$ were identified by analysis of the complete genome of H. pylori strain 26695 (Tomb et al., 1997). The function of the feo gene in iron uptake has been recently confirmed (Velayudhan et al., 1997). Iron at elevated concentrations repressed the production of the putative receptors for lactoferrin and for haemin (Dhaenens et al., 1997; Worst et al., 1996), providing evidence for regulation of iron uptake by the ferric uptake regulator protein Fur (Schaeffer et al., 1985; Stojiljkovic et al., 1994; Earhart, 1996; Genco \& Desai, 1996). A gene with significant homology to fur of other bacteria was identified within the $H$. pylori genome (Tomb et al., 1997) and the function of the gene product was confirmed (Bereswill et al., 1998b). The fact that in other pathogenic bacteria virulence genes are part of the Fur regulon (Litwin \& Calderwood, 1993) suggests that iron-dependent regulation could be also of importance for the host interaction.

The intracellular amount of free ferrous iron is controlled by the iron-binding protein ferritin, which incorporates ferrous iron and stores the ferric iron formed after oxidation in the central cavity of the molecule (Harrison \& Arioso, 1996). The native form of the eukaryotic ferritins and of the ferritin from Escherichia coli is a multimer of 24 subunits surrounding an inner space in which about 4500 iron molecules can accumulate (Harrison \& Arioso, 1996; Hempstead et al., 1994).

The $19 \mathrm{kDa}$ ferritin protein Pfr of H. pylori (Frazier et al., 1993) is homologous to eukaryotic and prokaryotic ferritins, and does not contain haem (Doig et al., 1993). This feature distinguishes Pfr from the bacterioferritins, which represent a different family of iron-binding proteins (Yariv et al., 1981; Harrison \& Arioso, 1996). It is not clear whether $H$. pylori does possess a bacterioferritin. The Dps-like protein encoded by the napA gene is only distantly related to this protein family (Evans et al., 1995a, b). Overproduction of the H. pylori pfr gene in $E$. coli caused accumulation of iron and gave rise to the formation of paracrystalline inclusions (Frazier et al., 1993). Corresponding structures were found in the cytoplasm of some $H$. pylori strains, and immunohistochemical analysis revealed that the ferritin protein is localized in these structures. The ferritin function of the Pfr protein was further supported by the fact that characteristic domains responsible for the ferrooxidase function and for binding of iron are strictly conserved (Frazier et al., 1993; Hempstead et al., 1994) but the incorporation of iron into Pfr multimers was not shown.

The increased iron content of $E$. coli harbouring the $p f r$ gene from $H$. pylori on a plasmid led to the hypothesis that overexpression of the Pfr protein mediates an increase in iron uptake (Frazier et al., 1993), and it was speculated that this was due to ferritin-mediated inhibition of the Fur repressor. This assumption was further supported by the finding that ferritin genes from
H. pylori and from other bacterial species strongly derepressed the Fur-regulated $f h u F-$ reporter gene fusion in E. coli, as evaluated by the Fur titration assay (FURTA; Stojiljkovic et al., 1994).

In this study, heterologous expression including FURTA analysis in $E$. coli, and insertional inactivation of the $p f r$ gene, were performed to obtain further insights into the role of the ferritin gene in the iron metabolism of H. pylori.

\section{METHODS}

Bacterial strains, plasmids and growth conditions. Bacterial strains and plasmids used are listed in Table 1 . The H. pylori strains were grown on HHP blood agar in a microaerobic atmosphere at $37^{\circ} \mathrm{C}$ as previously described (Bereswill et al., 1998a). The E. coli strains were grown in Luria-Bertani (LB) medium (Miller, 1972). If neccessary the media were supplemented with the antibiotics tetracycline ( $\mathrm{Tc}, 20 \mathrm{mg} \mathrm{l}^{-1}$ ), chloramphenicol $\left(\mathrm{Cm}, 20 \mathrm{mg} \mathrm{l}^{-1}\right.$ ) or ampicillin (Ap, $100 \mathrm{mg}$ $\left.1^{-1}\right)$.

Monitoring of growth under conditions of iron starvation and metal overload. To test $H$. pylori wild-type and mutant strains for their susceptibility to metal overload and oxidative stress, the strains were grown on Brucella broth agar supplemented with $1 \% \beta$-cyclodextrin (BBC). Parameters for iron deprivation and overload were chosen as evaluated earlier (Bereswill et al., 1997b). Briefly, iron deprivation was established by addition of the iron chelator desferrioxamine $B$ (desferal) and confirmed by reduced growth. For conditions of metal overload, BBC agar was supplemented with chloride salts of ferric iron, ferrous iron, copper, or manganese. Oxidative stress was generated with the radical mediator paraquat (methyl viologen). Bacterial growth was monitored $3 \mathrm{~d}$ after subculture on the indicator medium and reassessed after $6 \mathrm{~d}$. The experiments with the $p f r$ mutants were performed without antibiotic supplementation.

Analysis of Fur activity. The activity of the Fur repressor was determined as described by Stojiljkovic et al. (1994) using the E. coli indicator strain $\mathrm{H} 1717$, which contains a lac $\mathrm{Z}$ reporter gene under the transcriptional control of the Fur-regulated fhuF promoter (Table 1). Briefly, the activity of LacZ was monitored by reading the colour of colonies on MacConkey agar (Difco) supplemented with ferrous or ferric cloride at concentrations of $10,50,100$ or $1000 \mu \mathrm{M}$ after $24 \mathrm{~h}$. The iron chelator $2^{\prime}, 2^{\prime}$-dipyridyl $(50 \mu \mathrm{M})$ was used to establish conditions of iron deprivation, as described by Zimmermann $e t$ al. (1989). In the absence of iron, colonies appeared red due to the expression of $\beta$-galactosidase. The addition of iron to the agar medium caused activation of Fur, which resulted in the formation of colourless colonies. All growth experiments were performed in triplicate.

DNA isolation and manipulation. The isolation and manipulation of DNA was performed according to standard protocols (Sambrook et al., 1989). Plasmid DNA was isolated from E. coli, previously grown in $100 \mathrm{ml} \mathrm{LB}$ medium, by anion-exchange chromatography using a kit (Qiagen).

The plasmid pSO10, which contains the $p$ fr gene of strain P1 on a $7.5 \mathrm{~kb} \mathrm{BamHI}$ fragment, originated from a plasmid-based DNA library consisting of BamHI-fragmented DNA cloned in plasmid pMin1 (Table 1). Clones carrying the $p f r$ region were selected by hybridization to a radioactively labelled degenerate oligonucleotide mixture (ATG GTN AAY AAR GAY GTN 
Table 1. Bacterial strains and plasmids

\begin{tabular}{|c|c|c|}
\hline Strain or plasmid & Relevant characteristics" & Reference or source \\
\hline \multicolumn{3}{|l|}{ H. pylori } \\
\hline ATCC 43504 & wt, $\operatorname{cag} A^{+} v a c A(\mathrm{~s} 1 \mathrm{a} / \mathrm{m} 1)$ & ATCC \\
\hline G27 & $\mathrm{wt}, \operatorname{cag} A^{+} v a c A(\mathrm{~s} 1 \mathrm{~b} / \mathrm{m} 1)$ & Censini et al. (1996) \\
\hline G27-PFR1, -2, -3 & $\begin{array}{l}\text { G27 pfr::cat, pfr gene inactivated by insertion of the promoterless cat } \\
\text { cassette from pTnMax } 5, \mathrm{Cm}^{r}\end{array}$ & This study \\
\hline NCTC 11638 & wt, $\operatorname{cag} A^{+} \operatorname{vacA}(\mathrm{s} 1 \mathrm{a} / \mathrm{m} 1)$ & Bukanov \& Berg (1994) \\
\hline P1 & wt, $\operatorname{cag} A^{+} \operatorname{vac} A(\mathrm{~s} 1 \mathrm{a} / \mathrm{m} 1)$ & Odenbreit et al. (1996a) \\
\hline 151 & wt, $\operatorname{cag} A^{+} \operatorname{vacA}(\mathrm{s} 1 \mathrm{~b} / \mathrm{m} 1)$ & Bereswill et al. (1997a) \\
\hline \multicolumn{3}{|l|}{ E. coli } \\
\hline DH $5 \alpha$ & $\mathrm{F}^{-}$endA1 bsdR17 $\left(\mathrm{r}_{\mathrm{k}}{ }^{-} \mathrm{m}_{\mathrm{k}}{ }^{+}\right)$supE44 thi recA1 gyrA96 relA1 $\Delta$ lacZM15 & BRL \\
\hline H1443 & aroB araD lac rpsL thi & Zimmermann et al. (1989) \\
\hline H1717 & aroB fbuF:: $\lambda$ placMu $\mathrm{Km}^{\mathrm{r}}$ & Stojilikovic et al. (1994) \\
\hline 2136 & araD139 $\Delta($ lac $) U 169$ strA thi-1, $\mathrm{cI}_{857}$ on $\lambda$ prophage & Pohlner et al. (1993) \\
\hline \multicolumn{3}{|l|}{ Plasmids } \\
\hline pBluescript $\mathrm{KS}^{+}$ & $o r i_{\mathrm{ColEI}}$, plasmid vector, Ap & BRL \\
\hline pEV40b & $\begin{array}{l}\text { ori } i_{\mathrm{COIEI}} \mathrm{P}_{\lambda \mathrm{PL}} \text {, expression vector for fusion of genes with MS2 DNA } \\
\text { polymerase and six histidine residues, Ap }\end{array}$ & Pohlner et al. (1993) \\
\hline pGEMSZ'f & ori $i_{\mathrm{COlEI}}$, plasmid vector, Ap & Promega \\
\hline pMin1 & ori $_{\mathrm{COlEI}} \mathrm{Tc}^{\mathrm{r}}$ ori $\mathrm{T} \operatorname{ter}_{\mathrm{fd}} \operatorname{ter}_{\mathrm{trpA}}$ & Kahrs et al. (1995) \\
\hline pPFR1 & $\begin{array}{l}\text { pGEM5Z'f with a } 0.65 \mathrm{~kb} \text { insert carrying the complete } p \text { fr gene of } H . \\
\text { pylori strain P1, Ap }\end{array}$ & This study \\
\hline pPFR1-CAT & pPFR1 $p f r:: c a t_{\mathrm{GC}}, \mathrm{Ap} \mathrm{Cm}$ & This study \\
\hline pPFR2 & $\begin{array}{l}\text { pGEM5Z'f with a } 0.45 \mathrm{~kb} \text { insert carrying the partially deleted } p \text { fr gene } \\
\text { from } H \text {. pylori strain } \mathrm{P} 1, \mathrm{Ap}\end{array}$ & This study \\
\hline pFTN1 & $\begin{array}{l}\text { pGEM5Z'f with a } 0.8 \mathrm{~kb} \text { PCR product carrying the } f t n(r s g A) \text { gene } \\
\text { from } E \text {. coli strain } \mathrm{H} 1443, \mathrm{Ap}\end{array}$ & This study \\
\hline pSO10 & $\begin{array}{l}\text { pMin1 with a } 7.5 \mathrm{~kb} \text { chromosomal BamHI fragment carrying the } p f r \\
\text { gene from } H . \text { pylori strain P1, Tc }\end{array}$ & This study \\
\hline pSO20 & pfr gene from $H$. pylori strain P1 cloned into pEV40b, Ap & This study \\
\hline $\mathrm{pTn} \operatorname{Max} 5$ & cat $_{\mathrm{GC}}$ res orifd $\operatorname{tnp} R \operatorname{tnp} A \operatorname{lacl}^{\mathrm{q}} \mathrm{Cm}$ & Kahrs et al. (1995) \\
\hline
\end{tabular}

"wt, wild-type. Antibiotic-resistance markers: Ap, ampicillin; $\mathrm{Cm}$, chloramphenicol; Tc, tetracycline. The $c a g A$ status and the vacA allele type of the H. pylori strains were determined as previously described (Atherton et al., 1995; Strobel et al., 1998). AAR) derived from the N-terminal sequence of the Pfr protein
(Doig et al., 1993).

DNA sequence analysis of the pfr region. Defined restriction fragments of the insert in plasmid pSO10 covering the $p f r$ gene were subcloned in pBluescript II KS and sequenced. The DNA sequence of the $p f r$ region was determined by the dideoxynucleotide chain-termination method using a PRISM Ready Reaction Dye Cycle Sequencing Kit (ABI) with fluorescencelabelled primers. Nucleotide and protein sequence comparisons were performed using the BESTFIT and PILEUP algorithms of the UWGCG computer software. The DNA sequences of the $p f r$ regions from $H$. pylori strains NCTC 11638 and 26695 were obtained from the EMBL Database entry S54729 and from the Internet [tigr.org/tdb/mdb/hpdb/ hpdb.html - provided by The Institute for Genomic Research (TIGR), Rockville, MD, USA], respectively. The $p f r$ gene is identical with the ORF HP0653 in the complete sequence of strain 26695.

Isolation of RNA and primer extension analysis. Total RNA was isolated from $H$. pylori strain $\mathrm{P} 1$ and from $E$. coli $\mathrm{DH} 5 \alpha(\mathrm{pSO} 10)$ by a modification of a method originally described by Chirgwin et al. (1979). Briefly, bacteria grown on agar plates were resuspended in $400 \mu \mathrm{l}$ ice-cold TES $(10 \mathrm{mM}$ Tris/ $\mathrm{HCl} \mathrm{pH} 8,100 \mathrm{mM}$ EDTA, $100 \mathrm{mM} \mathrm{NaCl}$ ). After addition of $400 \mu \mathrm{l}$ TES containing $1 \% \operatorname{SDS}\left(95^{\circ} \mathrm{C}\right)$, a twofold extraction of the suspension with hot phenol $\left(65^{\circ} \mathrm{C}\right)$ was performed, the water phase was diluted with $1.2 \mathrm{ml} 4 \mathrm{M}$ guanidinium thiocyanate $(0 \cdot 1 \mathrm{M}$ Tris $/ \mathrm{HCl} \mathrm{pH} 7 \cdot 5,2 \% \quad \beta$ mercaptoethanol and $1 \%$ Nonidet-P40) and homogenized by shearing (passage through a $23-25 \mathrm{G}$ needle). The homogenate was centrifuged through a $1 \mathrm{ml} \mathrm{CsCl}$ cushion $(6 \mathrm{M} \mathrm{CsCl}$ in $10 \mathrm{mM}$ Tris $/ \mathrm{HCl} \mathrm{pH} \mathrm{7.5,} 1 \mathrm{mM}$ EDTA) at $150000 \mathrm{~g}$ for $18-20 \mathrm{~h}$ at $20^{\circ} \mathrm{C}$. The RNA pellet was resuspended in water and precipitated in ethanol. Oligonucleotide PFR-R3 (Table 2) was labelled at the $5^{\prime}$-end with $\left[\gamma^{32} \mathrm{P}\right]$ ATP $(1.5 \mathrm{pmol})$ and hybridized to $20 \mathrm{mg} H$. pylori RNA in avian myeloblastosis virus (AMV) buffer $(50 \mathrm{mM}$ Tris $/ \mathrm{HCl} \mathrm{pH} \mathrm{8.3,40} \mathrm{mM} \mathrm{KCl,}$ $5 \mathrm{mM}$ DTT) by heating at $95^{\circ} \mathrm{C}$ for $5 \mathrm{~min}$ and slow cooling at $42{ }^{\circ} \mathrm{C}$ for $15 \mathrm{~min}$. The annealing mixture was supplemented with $0.8 \mathrm{mM}$ each of the four dNTPs. AMV reverse transcriptase (USB) was added to extend the primer for $45 \mathrm{~min}$ at $42^{\circ} \mathrm{C}$. The sequencing reaction was performed using plasmid pSO10 as template. The Sequenase version 2.0 DNA Sequencing kit (USB) was used according to the instructions provided, and the probes were run on a $7 \%$ sequencing gel. 
Table 2. Primer oligonucleotides

\begin{tabular}{|ll|}
\hline Designation & \multicolumn{1}{c|}{ Sequence (position in the $\boldsymbol{p} \boldsymbol{f}$ r region) } \\
\hline FTN-L1 & ATCTTCGCTGATTAAAG \\
FTN-R4 & GCCGGAGAGCATTAGTT \\
GEM-L & CGACGGCCAGTGAATTG \\
GEM-R & TATGGTCGACCTGCAGG \\
PFR-L1 & TTTTGACCTAATTCTCA (817) \\
PFR-L2 & AGACATCATTAAGTTGC (1007) \\
PFR-L3 & GACTGAATTCATGTTATCAAAAGACATC (996) \\
PFR-R1 & ATTGTTTTCACTTCATC (1617) \\
PFR-R2 & AGATTTCCTGCTTTTAG (1496) \\
PFR-R3 & CATTTCCTTATTCACTTGTTCG (1049) \\
PFR-R4 & GACTAGATCTCCCATCTCCTTATGGCAC \\
CAT-L1 & CCGAGATTTTCAGGAG \\
CAT-R1 & ACGCCCCGCCCTGCC \\
\hline
\end{tabular}

PCR amplification, cloning and insertional inactivation of the pfr gene. The primer oligonucleotides used are listed in Table 2. Amplification by PCR and cloning of the PCR products was performed using Tth DNA polymerase (Pharmacia) as described previously (Bereswill \& Geider, 1997; Bereswill et al., 1997a). The primers PFR-L1, -R1, -L2 and -R2 were deduced from the $p f r$ sequence of strain P1 (EMBL accession number Y16068). The primer combinations PFR-L1/-R1 and -L2/-R2 were used to amplify the complete $p f r$ gene from isolated DNA of various $H$. pylori strains (Fig. 1a) and the products were cloned into plasmid pGEM5Z'f. The cloning of the PCR products amplified from DNA of $H$. pylori strain P1 resulted in plasmids pPFR1 and pPFR2, carrying a complete or a partially deleted version of the $p f r$ gene, respectively (Fig. 1a). The deleted version of $p f r$ in pPFR2 lacks the start and stop codons but carries most of the coding sequence. The correct insertion and the direction of the $p f r$ DNA relative to the lac $Z^{\prime}$ gene in the cloning vector was performed by sequence analysis with primers GEM-L and GEM-R, which flank the multiple cloning site in plasmid pGEM5Z'f. In plasmid pPFR1 the $p f r$ gene was inserted against the transcriptional direction of the lac $Z$ promoter present in the cloning vector.

Inactivation of the $p f r$ gene in pPFR1 yielded plasmid pPFR1CAT (Fig. 1a) which was constructed by ligating the promoterless CAT cassette amplified from plasmid pTnMax5 (Kahrs et al., 1995) with primers CAT-L1 and CAT-R1 into the BssHII site in the middle of the $p f r$ gene. The integration of the cassette in pPFR 1 was selected by growth of transformants of E. coli $\mathrm{DH} 5 \alpha$ with the antibiotics $\mathrm{Cm}$ and Ap. The direction of the cassette relative to the $p f r$ gene was confirmed by restriction analysis with appropriate enzymes.

The primer pair FTN-L1/-R4 was used to amplify the complete $f t n(r s g A)$ gene from E. coli strain H1443. The primer-binding sites were deduced from sequence information in the EMBL database (accession number X53513; Izuhara et al., 1991). The PCR product was cloned as described above. The resulting plasmid pFTN1 served as control in some experiments.

The PCR-directed determination of the $v a c A$ genotype was performed as described earlier (Atherton et al., 1995; Strobel et al., 1998).

Transformation of $\boldsymbol{H}$. pylori for achievement of marker exchange. Two different approaches were successfully used to achieve marker-exchange mutagenesis of the $p f r$ gene in $H$. pylori strain G27. With both methods, cells in which marker exchange had taken place were selected on BBC agar containing $\mathrm{Cm}\left(10 \mathrm{mg} \mathrm{l}^{-1}\right)$. Resistant colonies were subcultured on BBC agar with $\mathrm{Cm}$.

Protocol 1. Bacteria were grown on BBC agar until a faint cell layer was formed. Then $5 \mu \mathrm{g}$ of the PCR product amplified with primers PFR-L1/-R1 from pPFR1-CAT or of the plasmid pPFR1-CAT $(5 \mu \mathrm{l})$ were separately applied on the surface of the cell layer. The bacteria were then grown for another $48 \mathrm{~h}$ to allow uptake of DNA by natural transformation.

Protocol 2. Bacteria grown for $2 \mathrm{~d}$ were resuspended in $100 \mu \mathrm{l}$ calcium chloride solution $(100 \mathrm{mM})$. After cooling on ice for $1 \mathrm{~h}, 5 \mu \mathrm{g}$ of the PCR product mentioned above was added and the cells were incubated for a further $1 \mathrm{~h}$ on ice. Then the suspension was heated for $1 \mathrm{~min}$ at $42^{\circ} \mathrm{C}$ and cooled again on ice for $2 \mathrm{~min}$. After addition of $300 \mu \mathrm{l}$ Brucella broth the cells were incubated at $37^{\circ} \mathrm{C}$ for $1 \mathrm{~h}$ with mild shaking.

Production of Pfr antiserum. The $p f r$ gene on plasmid pSO10 was amplified by PCR with primers PFR-L3 and PFR-R4, which contain restriction sites for EcoRI and BamHI, respectively. The amplified DNA fragment was cut with both enzymes and cloned into the expression vector pEV40b. The resulting plasmid pSO20 (Fig. 1a) carried the $p$ fr gene fused inframe to the MS2 polymerase gene on the plasmid. After expression in E. coli strain 2136 and purification (Pohlner et al., 1993), the fusion protein was used to raise a polyclonal antiserum, AK198, in a New Zealand rabbit.

Protein electrophoresis and immunoblot analysis. Protein concentration was measured by the Lowry method. Gelelectrophoretic separation and analysis of proteins was performed by the method of Laemmli (1970). Bacteria previously grown on agar were resuspended in sample solution. After solubilization by boiling for $5 \mathrm{~min}$ the proteins were electrophoretically separated on a $15 \%$ SDSpolyacrylamide gel. Proteins were visualized by staining with Coomassie brilliant blue.

For immunoblot analysis the proteins separated by SDSPAGE were blotted onto a positively charged membrane (Immobilon) and analysed with the Pfr antiserum AK198 (see above). The bound rabbit antibodies were detected with a protein A-alkaline phosphatase conjugate (Sigma) followed by incubation with nitroblue tetrazolium. In some experiments 
binding of antibodies was detected by using light emission. In this case the blot was developed using a chemiluminescent alkaline phosphatase substrate and the signal was visualized by exposure to an X-ray film (Kodak).

Element-specific electron microscopy. Bacteria previously grown under iron deprivation or iron overload, as described above, were subjected to electron microscopy as previously described by Bode et al. (1993). The presence of iron, phosphorus and oxygen was detected by electron-spectroscopic imaging (ESI) and electron energy-loss-spectroscopy (EELS) according to standard procedures (Bode et al., 1993). To visualize bacterial structures, electrons were used with an energy loss of $283 \mathrm{eV}$ for carbon. The elemental composition of characteristic cytoplasmic structures was then analysed and visualized using specific energy loss of oxygen $(532 \mathrm{eV})$, phosphorus $(132 \mathrm{eV})$ and iron $(708 \mathrm{eV})$.

\section{RESULTS}

\section{Cloning and genetic analysis of the pfr gene from H. pylori strain P1}

To investigate the genetic variability of the $p f r$ gene in different $H$. pylori strains, the $p f r$ gene from strain P1 was sequenced on both strands by using plasmid pSO10 as template. The comparison of the nucleotide sequence to the $p f r$ regions of $H$. pylori strains NCTC 11638 and
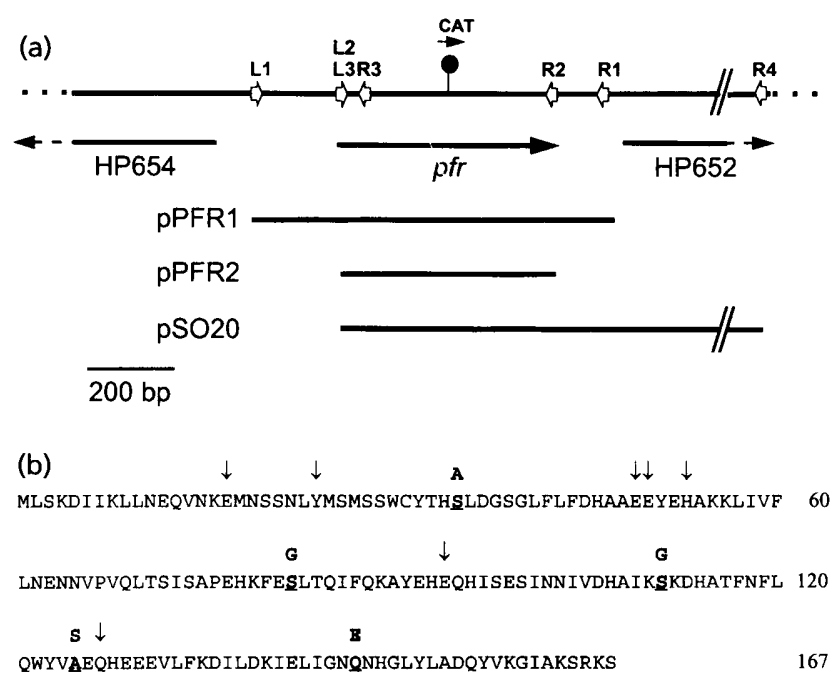

Fig. 1. (a) Schematic representation of the DNA region comprising the pfr region in $H$. pylori strain $\mathrm{P} 1$. The pfr gene and the neighbouring ORFs are marked by the black arrows. The upper line represents the pfr region of $H$. pylori strain P1 cloned in pSO10. The open arrowheads indicate the locations for binding sites of oligonucleotide primers. The exact positions of primers are given in Table 2. The DNA fragments subcloned in plasmids pPFR1, pPFR2 and pSO20 are underlined. The filled black circle marks the insertion of the cat gene present in PPFR1-CAT and in the Pfr-deficient mutant strains. The transcriptional direction of the cat gene is indicated by the small arrowhead. (b) Deduced amino acid sequence of the Pfr protein from $H$. pylori strain P1. The black arrows mark amino acids which are highly conserved within ferritins from various species and thought to be involved in binding of iron. Residues which were found to be exchanged in Pfr proteins from $H$. pylori strains NCTC 11638, G27 and 26695 are underlined and in boldface.
26695 (Frazier et al., 1993; Tomb et al., 1997) revealed that the $p f r$ coding region and parts of the flanking DNA regions are conserved. The presence of the $p f r$ gene in different strains (see Table 1) was confirmed by PCR with primers deduced from the $p f r$ gene of strain P1 (Fig. 1). Using primers PFR-L1/R1 or PFR-L2/R2 single PCR products of the expected size were generated from DNA of all strains as target (not shown). The PCR product carrying the $p f r$ region of strain G27 was also sequenced. The nucleotide sequences of the $p f r$ genes from strains NCTC 1168, P1, and G27 were found to be $99 \%, 99 \%$ and $98 \%$ identical with $p f r$ in strain 26695. Two ORFs, located upstream and downstream from the $p f r$ gene, were identified in strain P1. These are homologous to ORFs HP0654 and HP0652 which flank the $p f r$ locus (HP0653) in strain 26695 (Fig. 1a). Similar identity values were found for the deduced amino acid sequences of the Pfr proteins ( $>97 \%$ identity). The amino acid exchanges concern residues known not to be involved in the function of the ferritin (Fig. 1b; Harrison \& Arioso, 1996).

\section{Transcriptional analysis of the pfr gene}

Transcriptional start sites in front of the $p f r$ gene were determined by primer extension analysis of total RNA isolated from $H$. pylori strain $\mathrm{P} 1$ and from E. coli $\mathrm{DH} 5 \alpha(\mathrm{pSO} 10)$. A strong primer extension product was produced using RNA preparations from $H$. pylori and from $\mathrm{DH} 5 \alpha(\mathrm{pSO} 10)$ as target. This indicated the presence of a transcriptional start site at position -28 with respect to the ATG start codon (Fig. 2a, lanes 1 and 3; S1). A Pribnow box $(-10$, TATAAT) and a putative -35 region (TTTACT) indicated that the promoter structure preceding this start site shares significant homology with the $\sigma^{70}$ consensus of E. coli (Fig. 2b, S1).

The second primer extension product, which was exclusively generated from RNA of $H$. pylori strain P1 (Fig. 2a, lanes 1 and 3, S2), identified an additional RNA start site at position -70 relative to the start codon (Fig. $2 \mathrm{~b}, \mathrm{~S} 2)$. The putative promoter preceding this site has some characteristics of the $\sigma^{70}$ consensus of $E$. coli but is not as well conserved as the first site.

Both transcriptional start sites were completely conserved in strains P1, NCTC 11638 and 26695. Further computational analysis of the DNA region downstream from the $p f r$ gene identified a perfect inverted repeat (CAAAAACN ${ }_{5}$ GTTTTTG) located 17 nucleotides downstream from the TAA stop codon (Fig. 2b). This motif, although it causes a stem-loop of low stability, could represent a transcriptional terminator structure and was also completely conserved among strains.

\section{Functional characterization of the pfr gene in $E$. coli}

It has been reported earlier that bacterial ferritin genes on plasmids, including $r s g A(f t n)$ and $p f r$ from $E$. coli and from $H$. pylori respectively, cause inactivation of the ferric uptake repressor Fur in E. coli as indicated by a positive phenotype in the FURTA. 
(a)

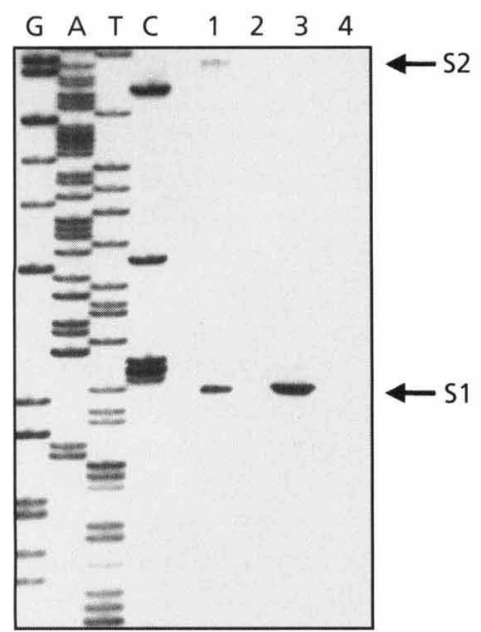

(b)

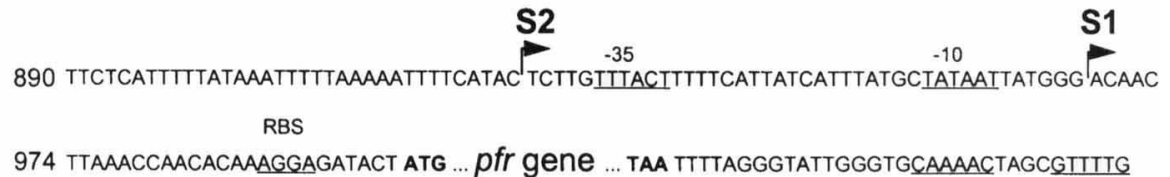

Fig. 2. Determination of the transcriptional start points of the pfr gene. (a) Autoradiograph showing the products $S 1$ and S2 obtained by primer extension analysis of RNA from $H$. pylori strain P1 (lanes 1 and 2) and from E. coli DH5 $\alpha(\mathrm{pSO} 10)$ (lanes 3 and 4). In lanes 2 and 4 the RNA preparation was treated with RNase prior to primer extension analysis. Lanes $G$, $A, T$ and $C$ contain products from sequencing reactions specific for guanine, adenine, thymidine and cytosine residues, respectively. (b) Location of the transcriptional start sites and of the putative promoter structures in the pfr upstream region. The arrows mark the transcriptional start points $\mathrm{S1}$ and $\mathrm{S2}$ as determined by primer extension analysis (see a). The ribosome-binding site (RBS) in front of the pfr gene is underlined. The start and the stop codon are in boldface. The perfect inverted repeat located downstream from $p f r$ is underlined. Nucleotide positions corresponding to the sequence of the pfr region deposited in the EMBL database (Y16068) are given to the left.

To investigate whether the FURTA could be used to isolate the $p f r$ gene and possibly other genes involved in iron metabolism of $H$. pylori, plasmid-based DNA libraries of strains NCTC 11638 and P1 were transferred into E. coli $\mathrm{H} 1717$ and single colonies of the transformants were screened on MacConkey agar containing $100 \mu \mathrm{M}$ iron. From each library analysed, three out of 1000 transformants appeared red, representing a Furderepressed phenotype. PCR analysis with the primer combination PFR-L2/-R2 detected the $p f r$ gene in three of the plasmids (not shown), confirming that the ferritin gene from $H$. pylori is detected by the FURTA. The remaining plasmids, which gave no signal in the $p f r-$ specific PCR assay, were either not stable as indicated by the loss of the phenotype after retransformation into strain $\mathrm{H} 1717$, or contained the fur gene from strain NCTC 11638 as described elsewhere (Bereswill et al., 1998b).

It has been earlier hypothesized that the inhibition of Fur in E. coli $\mathrm{H} 1717$ by ferritin genes on plasmids is caused by the activity of the ferritin protein (Stojiljkovic et al., 1994). To investigate the inhibition of Fur by ferritin in more detail, plasmids pPFR1, pPFR1-CAT and pPFR2, carrying the complete, an inactivated, or a partially deleted version of the $p f r$ gene from strain $\mathrm{P} 1$, respectively (Fig. 1a), were constructed (see Methods) and separately transferred into E. coli strain H1717. The results of the analysis by FURTA, summarized in Table 3 , indicated that only the intact gene on plasmid pPFR1 mediated de-repression of the $f b u F:$ : lac $Z$ reporter even
Table 3. FURTA analysis of the pfr and ftn genes in E. coli $\mathrm{H} 1717$

\begin{tabular}{|llc|}
\hline Plasmid & Genotype & $\begin{array}{c}\text { LacZ expression on MC } \\
\text { with iron* }\end{array}$ \\
\hline pGEM5Z'f & $p f r$ & - \\
pPFR1 & $p f r:: c a t_{\mathrm{GC}}$ & + \\
pPFR1-CAT & $\Delta p f r \dagger$ & - \\
pPFR2 & $f t n(r s g \mathrm{~A})$ & - \\
pFTN1 & & + \\
\hline
\end{tabular}

* MC, MacConkey agar with $0 \cdot 05,0 \cdot 1$, and $1 \mathrm{mM}$ iron.,+ Red colour, fhuF: lac $Z$ derepression, weak Fur-activity; -, colourless, reflecting repression of $f h u F:$ :lac $Z$ by Fur.

$\dagger \Delta p f r$, partial $p f r$ gene (without the up- and downstream segments) (see Table 1 and Fig. 1).

in the presence of up to $1 \mathrm{mM}$ iron. Both insertional inactivation and deletion of the up- and downstream segments of the $p f r$ gene completely abolished this function. This indicated that the inhibition of Fur by pPFR1 is mediated by the catalytic activity of the Pfr protein rather than by binding of Fur to the $p f r$ DNA in the plasmid, which could cause the same phenotype.

The plasmid pFTN1, which carries the $f t n(r s g A)$ gene of E. coli, derepressed the fbuF:lacZ fusion in the same manner as plasmid pPFR1. 


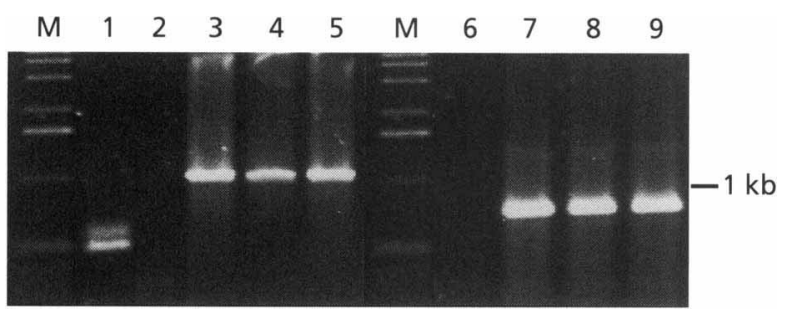

Fig. 3. Detection of the pfr and cat genes in the pfr-deficient mutant strains. About $10^{5}$ cells of the host strain G27 (lanes 1 and 6) and of the pfr-deficient mutant strains G27-PFR1-3 (lanes 3-5 and 7-9) were analysed by PCR with primer pairs PFR-L2/-R2 and CAT-L-R, which detect the pfr gene (lanes 1-5) and the presence of the cat ${ }_{G C}$ gene (lanes 6-9), respectively. In lane 2, PCR for detection of pfr was performed without target cells. The PCR products were separated on a $1.6 \%$ agarose gel and stained with ethidium bromide. The size of a selected marker DNA $(M)$ is given to the right. The PCR product amplified with primers PFR-L2/-R2 is 489 bp in size. The CAT cassette amplified with primers CAT-L1/-R1 is $703 \mathrm{bp}$ in size.

\section{Inactivation of the pfr gene in $\mathrm{H}$. pylori}

The $p f r::$ cat gene in plasmid pPFR1-CAT was used to achieve marker exchange mutagenesis in $\mathrm{H}$. pylori. The H. pylori wild-type strains listed in Table 1 were transformed with the $p$ f $r:$ :cat gene fusion and recombinants carrying the resistance marker in the chromosome were selected. Two different approaches (see Methods), using linear or circular DNA were successful in mutagenizing strain G27, yielding the mutant strains G27-PFR1, -PFR2 and -PFR3.

Microscopical appearance and biochemical tests revealed that the mutants presented as spiral-shaped rods which were microaerophilic and positive for urease and for catalase. The PCR-directed typing of the vacA gene (Atherton et al., 1995) further confirmed the mutants as derivatives of $H$. pylori G27, which harbours a $v a c A$ gene of allele type $\mathrm{s} 1 \mathrm{~b} / \mathrm{m} 1$ (not shown).

The correct insertion of the cat cassette within the chromosomal $p f r$ gene was analysed by PCR using the primer combinations PFR-L2/-R2 and CAT-L/-R (Fig. 3). The amplification of the $p f r$ gene in the mutant strains generated a $1 \cdot 2 \mathrm{~kb}$ product (Fig. 3, lanes 3-5) which was bigger than the product obtained from wildtype strain G27 by an amount corresponding to the size of the cat cassette (Fig. 3, lane 1). The cat gene was exclusively amplified from the mutant strains (Fig. 3, lanes 6-9). Analysis of DNA from strains G27 and G27PFR1 by Southern hybridization with DNA probes specific for $p f r$ and for cat proved additionally that the cat cassette was correctly inserted and that the mutant strains carry a single insertion of the marker (not shown).

\section{Detection of the ferritin protein}

To study the production of the Pfr protein in H. pylori and in E. coli total proteins were analysed by SDS-PAGE and by Western immunoblotting using the polyclonal

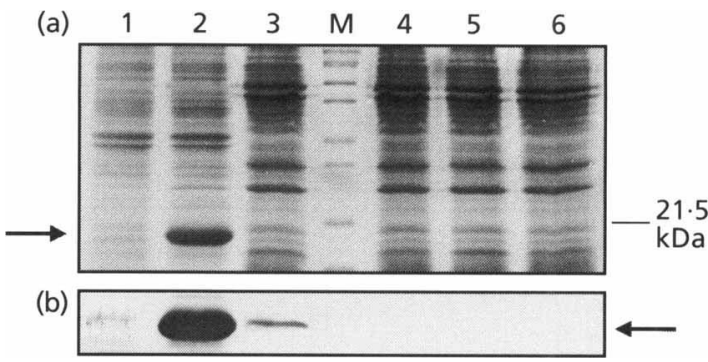

Fig. 4. Analysis of the Pfr protein by SDS-PAGE (a) and Western blotting (b). Lane 1, E. coli H1717(pGEM5Z'f); lane 2, H1717(pPFR1); lane 3, H. pylori G27; lane 4, G27-PFR1; lane 5, G27-PFR2; lane 6 G27-PFR3. (a) Proteins were separated on a $15 \%$ polyacrylamide gel and stained with Coomassie blue. The size of a selected marker protein $(\mathrm{M})$ is given to the right. The arrow to the left marks the Pfr protein overexpressed by $E$. coli H1717(pPFR1). (b) Detection of the ferritin protein by Western blot analysis of the proteins shown in (a) with the Pfr-specific antiserum AK198. The band which represents the Pfr protein is marked by the arrow to the right.

antiserum AK198 (Fig. 4). The analysis of protein profiles by Coomassie staining revealed that the presence of plasmid pPFR1 in strain H1717 gave rise to an additional protein band of around $19 \mathrm{kDa}$ which was not produced by H1717 carrying the plasmid vector alone (Fig. 4a, lanes 1 and 2). The protein profiles obtained for the H. pylori parent strain and for the three mutants were identical (Fig. 4a, lanes 3-6).

Immunoblot analysis with the Pfr-specific antiserum confirmed that the $19 \mathrm{kDa}$ protein overproduced by $E$. coli H1717 (pPFR1) is identical with Pfr (Fig. 4b, lane 2). A weak signal, which was probably due to a weak crossreaction of the antibodies with the ferritin protein Ftn (RsgA) from E. coli was also seen in H1717 (pGEM5Z'f) (Fig. 4b, lane 1). The Pfr protein was also detected in the H. pylori parent strain G27 (Fig. 4b, lane 3) but not in the $p f r$-deficient mutants, indicating that the mutagenesis of the $p f r$ gene was successful (Fig. 4b, lanes 4-6).

\section{Growth characteristics of the pfr-deficient mutant strains}

To further investigate the role of $p$ fr in iron metabolism, the growth of the mutants under iron deprivation, iron overload and oxidative stress was monitored. The toxic (no growth) and the sublethal (growth inhibition about $50 \%$ ) concentrations of the metals iron, copper and manganese, of the iron chelator desferal and of the oxygen radical mediator paraquat were estimated by growing the $H$. pylori wild-type strains listed in Table 1 on BBC agar with increasing amounts of the agents. Iron and the other metals inhibited growth completely at concentrations of $3 \mathrm{mM}$. Desferal and paraquat were inhibitory at concentrations of $20 \mu \mathrm{M}$ and $10 \mu \mathrm{M}$, respectively. Sublethal concentrations are given in Table 4. Growth of all strains was not impaired in the presence of sodium chloride at concentrations of up to $3 \mathrm{mM}$, excluding the influence of osmotic stress. 
Table 4. Growth characteristics of pfr mutants compared to the parent strain

$\mathrm{BBC}$, Brucella broth with cyclodextrin. +, Growth; +/-, growth reduced to about $50 \%$; -, no growth.

\begin{tabular}{|c|c|c|c|c|c|c|c|c|c|}
\hline \multirow[t]{3}{*}{ Strain } & \multicolumn{9}{|c|}{ Growth on BBC agar with supplements indicated: } \\
\hline & \multirow[t]{2}{*}{ None } & \multicolumn{2}{|c|}{ Desferal } & \multicolumn{2}{|c|}{ Ferrous iron* } & \multicolumn{2}{|c|}{ Ferric iron* } & \multicolumn{2}{|c|}{ Paraquat } \\
\hline & & $(15 \mu M)$ & $(20 \mu \mathrm{M})$ & $(0.5 \mathrm{mM})$ & $(1 \mathrm{mM})$ & $(1 \mathrm{mM})$ & $(2 \mathrm{mM})$ & $(1 \mu \mathrm{M})$ & $(10 \mu M)$ \\
\hline G27 & + & $+1-$ & - & + & + & + & + & $+1-$ & - \\
\hline G27-PFR1-3 & + & $+1-$ & - & $+1-$ & - & $+1-$ & - & $+1-$ & - \\
\hline
\end{tabular}

*BBC agar supplemented with chloride salts of the metals.

Under conditions of oxidative stress or iron deprivation, the growth of the $p f r$ mutant strains was not different from the parental strain G27 (Table 4). However, in the presence of excess iron, the growth of the $p f r$ mutants was significantly impaired with respect to that of the parental strain: the addition of ferrous chloride at concentrations of $1 \mathrm{mM}$ and $0.5 \mathrm{mM}$ abolished or at least reduced growth of the mutants to about $50 \%$, respectively, whereas the growth of wild-type strain G27 was not impaired by elevated levels of ferrous iron (up to $2 \mathrm{mM}$ ). The elevated susceptibility of the mutants to killing by iron was more pronounced for ferrous chloride; ferric chloride caused a reduction in growth only at concentrations above $1 \mathrm{mM}$ and completely abolished growth at a concentration of $2 \mathrm{mM}$ (Table 4).

The $p f r$ mutants were also more susceptible to killing by copper and manganese. In the presence of these metals, the growth behaviour of the parent strain and of the mutants was identical to that observed for overload generated with ferrous iron (see above, Table 4).

\section{Visualization of iron-containing subcellular structures}

To further clarify the role of Pfr in the formation of ironcontaining subcellular structures, strain G27 and the $p f r$ mutant G27-PFR1 were grown under normal, iron-rich $(500 \mu \mathrm{M})$ or iron-depleted conditions and analysed by transmission electron microscopy (TEM) and by element-specific electron-spectroscopic imaging (ESI; Fig. 5). The latter technique allows specific analysis of the elemental composition of cellular structures (Bode $e t$ al., 1993).

Analysis by TEM did not detect significant differences between the $p f r$ mutant and the parent strain (Fig. 5a, b). Both strains consisted of curved rods and growth in presence of iron did not significantly change the cell morphology or the appearance of the cytoplasm.

In contrast, the analysis by ESI specific for iron revealed that the parental strain G27 harbours two types of ironcontaining cytoplasmic aggregates (Fig. 5c), which were exclusively formed upon growth in the presence of iron. Neither type of structure was detected in the mutant G27-PFR1 (Fig. 5d). When the parent strain was grown on BBC agar without iron supplementation, no ESI signal was detected in the cytoplasm, perhaps indicating that the cytoplasmic iron concentration was below the detection limit of the method. The pictures obtained were similar to that obtained for analysis of the mutant grown under iron-rich conditions (Fig. 5d).

Further analysis of the elemental composition of the iron-containing aggregates in strain G27 by ESI and electron energy-loss spectroscopy (EELS) specific for carbon, oxygen and phosphorus, respectively, revealed two types of iron-containing aggregates, which were clearly distinguishable by their morphology and by their elemental composition: the large amorphous vacuolelike aggregates (type I) of $0.05-0.20 \mu \mathrm{m}$ diameter contained iron in association with phosphorus and oxygen, whereas the small round granule-like structures (type II) of $0.02-0 \cdot 10 \mu \mathrm{m}$ diameter, consisted of iron and oxygen. Carbon was detected in both structures (Fig. 5e).

\section{Accumulation of the Pfr protein under conditions of iron overload}

The observation that the accumulation of iron in subcellular structures was induced by iron and was dependent on the presence of the intact ferritin gene led to the speculation that the ferritin protein could be positively regulated by iron and might have an influence on iron-dependent regulation in H. pylori. To further investigate these possibilities, total proteins from $H$. pylori strain G27 grown on BBC agar as well as under conditions of iron overload or iron deprivation, were analysed by SDS-PAGE (Fig. 6a). Growth in the presence of $1 \mathrm{mM}$ ferric or ferrous chloride significantly reduced the intensity of a small protein band of around $12 \mathrm{kDa}$ (Fig. 6a, lanes 2 and 3). The intensity of the $12 \mathrm{kDa}$ band was furthermore increased under conditions of iron deprivation (Fig. 6, lane 4) and clearly diminished in the pfr-deficient mutant G27-PFR1 (Fig. 6, lane 5).

Further analysis of the Pfr protein by immunoblotting with the Pfr-specific antiserum (Fig. 6b) revealed that iron overload caused significant accumulation of the ferritin protein (Fig. 6b, lanes 2 and 3), whereas iron deprivation resulted in a slight decrease in the intensity of the ferritin band (Fig. 6B, lane 4). Under conditions of 

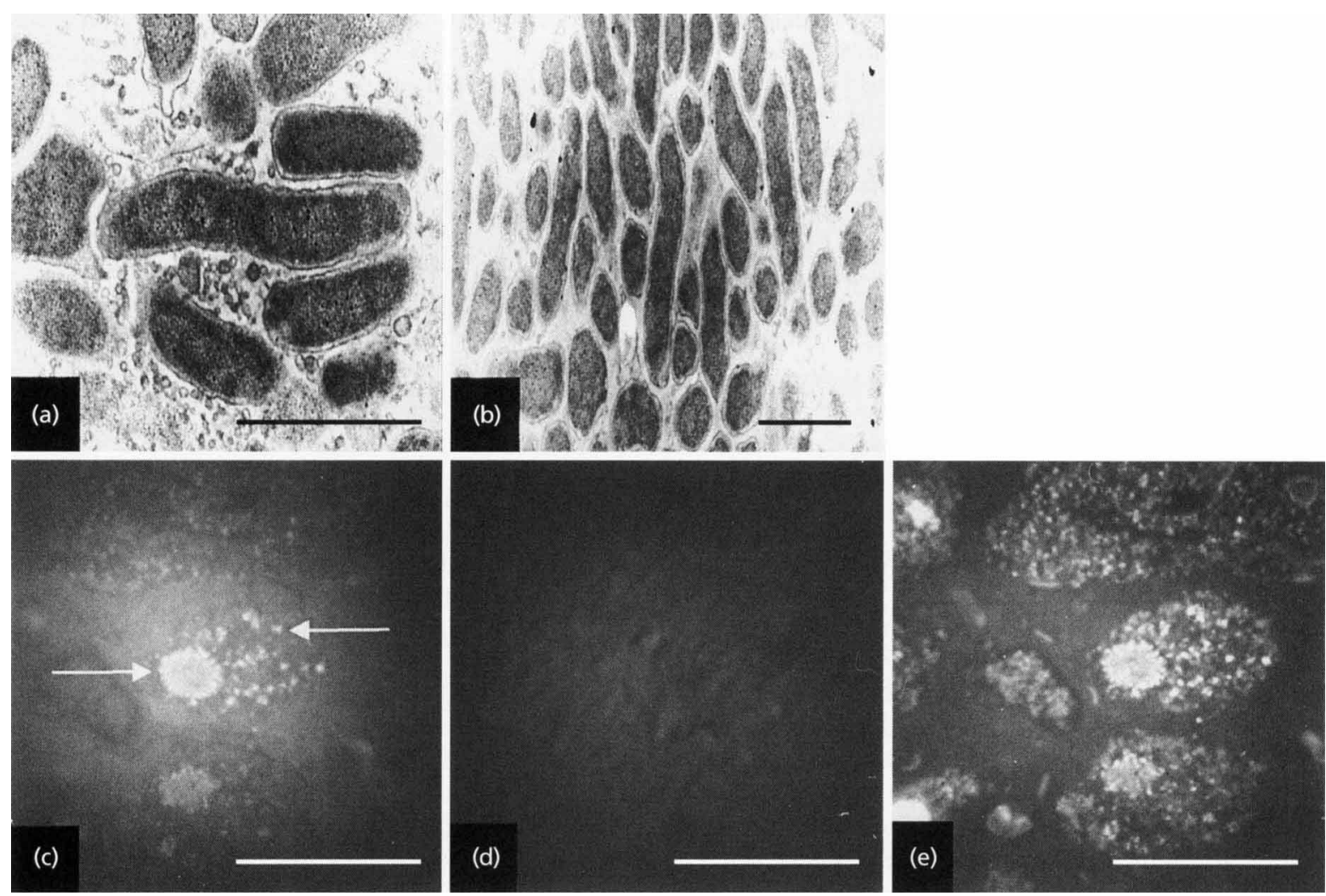

Fig. 5. Visualization of cytoplasmic iron aggregates in $H$. pylori. $(a, b)$ Transmission electron micrographs of the $H$. pylori parent strain G27 and of the pfr-deficient mutant strain G27-PFR1. (c-e) Analysis of cells by ESI specific for iron (c, d), and for carbon (e). Strains G27 (c, e) and G27-PFR1 (d) were grown in the presence of $1 \mathrm{mM}$ ferric chloride and analysed by electron microscopy using electrons with an energy loss of $283 \mathrm{eV}$ for carbon ( $\mathrm{C}_{\kappa}$ edge) and an energy loss of $708 \mathrm{eV}$ for iron ( $b, c ; \mathrm{Fe}_{123}$ edge). The iron-containing aggregates, which were detected only in strain $\mathrm{G} 27$, are marked by white arrows (c). Bars, $0.5 \mu \mathrm{m}$.

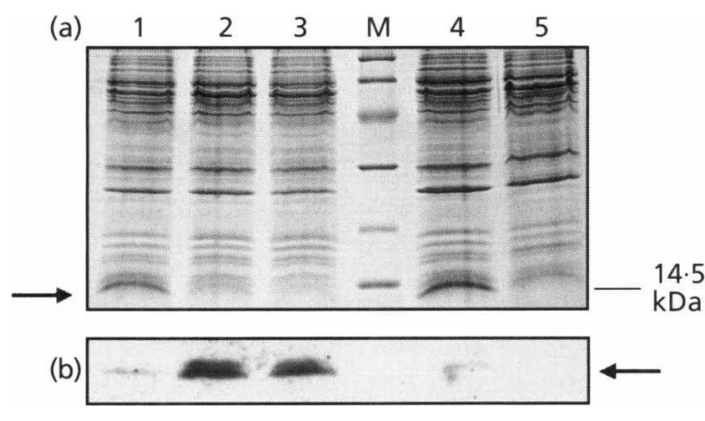

Fig. 6. Iron-dependent protein expression in $H$. pylori and analysis of the Pfr protein under conditions of iron overload. Total cell lysates from $H$. pylori strains G27 (lanes $1-4$ ) and G27PFR1 (lane 5) grown on BBC agar with various supplements were separated on a $15 \%$ polyacrylamide gel. Lanes 1 and 5 , BBC agar without supplements; lanes 2, 3 and 4, BBC agar with $1 \mathrm{mM}$ ferric chloride, $1 \mathrm{mM}$ ferrous chloride and $10 \mu \mathrm{M}$ desferal, respectively. The size of a selected marker protein (M) is given to the right. (a) Visualization of electrophoretically separated proteins by staining with Coomassie blue. The $12 \mathrm{kDa}$ protein band which disappeared in the presence of iron overload is marked by the black arrow to the left. (b) Detection of the Pfr protein with the specific antiserum AK198 by immunoblot analysis. The band corresponding to the Pfr protein is marked by the arrow to the right. iron overload, two bands of similar but not identical molecular mass were reproducibly detected (Fig. 6b, lanes 2 and 3). This might indicate that the ferritin protein is modified upon accumulation.

\section{DISCUSSION}

Populations of $H$. pylori exhibit genetic polymorphisms (Taylor et al., 1996) and it has recently been demonstrated that the chromosomal localization of the $p f r$ gene varies among strains (Jiang et al., 1996). The present analysis revealed that the ferritin gene is well conserved among strains. This finding provides evidence for positive selection of the $p f r$ gene, which is further supported by the fact that changes in the amino acid sequence of Pfr from different strains do not concern residues involved in the basic functions of the ferritin.

The viability of the $p f r$-deficient mutant strains in the presence of chloramphenicol indicated that the $p f r$ promoter is active at all growth stages. The two transcriptional start sites might indicate that the gene is constitutively expressed in H.pylori. This assumption is supported by the similarity of one binding site for RNA 
polymerase to $\sigma^{\mathbf{7 0}}$-dependent promoters, which are known to mediate continuous transcription of housekeeping genes in most bacterial species. This promoter is obviously responsible for transcription of the $p f r$ gene in $E$. coli and for the heterologous production of the protein in E. coli. The second transcriptional start site in front of the $p f r$ gene is active in $H$. pylori but not in $E$. coli. This observation might be explained by differences in the transcription machinery of both species or by the lack of a H. pylori-specific sigma factor which is essential for transcriptional activity of this promoter. The corresponding promoter might be involved in upregulation of the $p f r$ gene expression under different conditions, e.g. iron overload.

The fact that inactivation of Fur in E. coli H1717 was caused solely by the intact $p f r$ gene excluded the possibility that the repressor was titrated out by binding to a Fur-binding site present in the $p f r$-containing plasmid. These observations supported the earlier hypothesis that the Pfr protein inactivates Fur by removal of the ferrous iron cofactor (Stojiljkovic et al., 1994). The inhibition of Fur by ferritin may explain the earlier observation that the $p f r$ gene on a plasmid causes accumulation of iron in E. coli (Frazier et al., 1993). Based on these findings it can be hypothesized that the interaction of ferritin with Fur allows the bacteria to maintain iron uptake especially under conditions of iron overload. The resulting formation of iron deposits might contribute to survival under conditions of iron starvation.

Different approaches were applied to investigate whether the usage of circular or linear DNA, or the transformation of calcium-competent cells, is effective for creation of $H$. pylori mutants. The results showed that $H$. pylori is able to transport and to recombine both types of DNA at comparable efficiency. The fact that a protocol developed for transformation of calciumcompetent cells of $E$. coli resulted in recombinants indicated that H. pylori is transformable by this approach, but the calcium treatment had no influence on the transformation efficiency (not shown).

The biological function of the iron-containing aggregates detected in the cytoplasm of $H$. pylori is not known but it can be speculated that they represent deposits for iron and for phosphorus which could contribute to survival under unfavourable environmental conditions. Phosphorus and oxygen are typical components of the ferrihydrite core of prokaryotic and eukaryotic ferritins (Harrison \& Arioso, 1996; Wai et al., 1995; Bezkorovainy, 1987). Together with the earlier finding that the Pfr protein was detected within paracrystalline cytoplasmic arrays of H. pylori (Frazier et al., 1993), this elemental composition provides evidence that the ferritin is a major iron-containing component of the cytoplasm. The fact that the $p f r$ mutant lacked the iron-containing aggregates indicates furthermore that the Pfr protein plays a crucial role in the formation of these structures. This is in good agreement with the observation that heterologous expression of the ferritin genes from $H$. pylori and from $C$. jejuni caused the formation of paracrystalline inclusions in E. coli (Frazier et al., 1993; Wai et al., 1997). The fact that crystalline arrays were not detected by TEM analysis of strain G27 in the present study might be explained by differences in preparation or staining of the specimens. It is also possible that in strain G27 the inclusions are not dense enough to be detected by TEM.

Metal ions favour the formation of the toxic superoxide and hydroxyl radicals (Miller \& Britigan, 1997). The finding that the $p f r$ mutants were more susceptible to the toxicity of iron indicated that the $p f r$ gene is involved in metal resistance of $H$. pylori. The ferritin from $E$. coli can protect cells from the toxicity of iron (Touati et al., 1995). A ferritin-deficient mutant of Campylobacter jejuni was found to be more sensitive to killing by oxygen radicals (Wai et al., 1996). In contrast, under conditions of oxidative stress, growth of the $p f r$-deficient mutants of $H$. pylori did not significantly differ from the parent strain. This might indicate that in $H$. pylori detoxification of oxygen radicals is mediated by additional systems, which act independently of ferritin. In this context it seems noteworthy that $H$. pylori does possess superoxide dismutase (Spiegelhalder et al., 1993) and catalase (Odenbreit et al., 1996b), both involved in detoxification of oxygen radicals. Finally, the possibility has to be considered that $H$. pylori detoxifies oxygen radicals in an individual way. In this context it is interesting that $H$. pylori produces the oxygen-sensitive enzymes pyruvate: flavodoxin oxidoreductase (Por) and 2-oxoglutarate: acceptor oxidoreductase (Oor), which catalyse electron transfer via ferredoxin components to NADPH and are in this combination rarely established in bacteria (Hughes et al., 1997).

The finding that the $p f r$ mutant strains, beside their sensitivity to iron, were also more prone to killing by the metals copper and manganese suggests that the binding and sequestration of metals by Pfr is not specific for iron. The role of Pfr in resistance of $H$. pylori to other metals, including nickel, zinc or bismuth, which act as cofactors for H. pylori enzymes, or are used as therapeutic agents, is currently under investigation.

The induction of the formation of the cytoplasmic iron aggregates by iron concurs with the observation that the ferritin protein accumulated under conditions of iron overload. This upregulation makes sense, because the toxic effect of excess iron can be compensated by ferritin. Corresponding regulation of ferritins has been reported for other micro-organisms (Harrison \& Arioso, 1996). In eukaryotes production of ferritins is also positively regulated by iron. It can be speculated that the two promoters in front of the gene contribute to this regulation phenomenon. However, accumulation of ferritin under iron-rich conditions could also be mediated by translational or post-translational processes. The two bands observed in cells grown under iron-rich conditions could represent two forms of ferritin, one of which is modified and therefore migrates more slowly. 
The iron-mediated downregulation of the $12 \mathrm{kDa}$ protein provides further evidence that a Fur regulon exists in H.pylori. It can be hypothesized that the repression of this protein in the $p f r$-deficient mutants is caused by an increased activity of the Fur repressor which could be mediated by an elevated concentration of ferrous iron as a result of the absence of ferritin.

In summary, the results obtained support the idea of an interaction between ferritin and the iron uptake regulator Fur, as hypothesized earlier, and give new insights into the role of ferritin in iron metabolism of $H$. pylori. The iron resistance mediated by ferritin might be important for survival of the pathogen within its natural habitat, where it is faced with iron and other metals which originate from the diet.

\section{ACKNOWLEDGEMENTS}

U.W., S.O. and S.B. made equal contributions to this study. Parts of this work will be included in the MD thesis of U.W. The authors thank Drs Wolfgang Bredt and Rainer Haas for continous support and encouragement. Tanja Vey provided excellent technical assistance. The authors are also grateful to Drs Antonello Covacci and Klaus Hantke for providing strains G27 and H1717, respectively, and to Dr Steve Batsford, who critically corrected the manuscript. This work was supported by a grant from the Deutsche Forschungsgemeinschaft (DFG) to M.K. (Ki201/8-2).

\section{REFERENCES}

Asaka, M., Kimura, T., Kato, M., Kudo, M., Miki, K., Ogoshi, K., Kato, T., Tatsuga, M. \& Graham, D. Y. (1994). Possible role of Helicobacter infection in early gastric cancer development. Cancer 73, 2691-2694.

Atherton, J. C., Cao, P., Peek, R. M., Tummuru, M. K. R., Blaser, J. M. \& Cover, T. L. (1995). Mosaicism in vacuolating cytotoxin alleles of Helicobacter pylori. J Biol Chem 270, 17771-17777.

Bereswill, S. \& Geider, K. (1997). Characterization of the $r c s B$ gene from Erwinia amylovora and its influence on exopolysaccharide synthesis and virulence of the fire blight pathogen. J Bacteriol 179, 1354-1361.

Bereswill, S., Fassbinder, F., Voelzing, C., Haas, R., Reuter, K., Ficner, R. \& Kist, M. (1997a). Cloning and functional characterization of the genes encoding 3-dehydroquinate synthase (aroB) and tRNA-guaninc transglycosylase $($ tgt $)$ from Helicobacter pylori. Med Microbiol Immunol 186, 125-134.

Bereswill, S., Strobel, S., Lichte, F., Fassbinder, F. \& Kist, M. (1997b). Evaluation of microbiological parameters for the study of iron metabolism in Helicobacter pylori. Gut 41 (Suppl. 1), A10.

Bereswill, S., Fassbinder, F., Voelzing, C., Covacci, A., Haas, R. \& Kist, M. (1998a). Hemolytic properties and riboflavin synthesis of Helicobacter pylori: cloning and functional characterization of the ribA gene encoding GTP-cyclohydrolase II that confers hemolytic activity to Escherichia coli. Med Microbiol Immunol 186, 177-187.

Bereswill, S., Lichte, F., Vey, T., Fassbinder, F. \& Kist, M. (1998b). Cloning and characterization of the fur gene from Helicobacter pylori. FEMS Microbiology Lett 159, 193-200.

Bezkorovainy, A. (1987). Iron proteins. In Iron and Infection:
Molecular, Physiological and Clinincal Aspects, pp. 51-55. Chichester: Wiley.

Bode, G., Mauch, F., Ditschuneit, H. \& Malfertheiner, P. (1993). Identification of structures containing polyphosphate in Helicobacter pylori. J Gen Microbiol 139, 3029-3033.

Buck, G. E. (1990). Camplyobacter pylori and gastroduoenal disease. Clin Microbiol Rev 3, 1-12.

Bukanov, N. O. \& Berg, D. E. (1994). Ordered cosmid library and high resolution physical genetic map of Helicobacter pylori strain NCTC 11638. Mol Microbiol 11, 509-523.

Censini, S., Lange, C., Xiang, Z., Crabtree, J. E., Ghiara, P., Borodovsky, M., Rappuoli, R. \& Covacci, A. (1996). Cag, a pathogenicity island of Helicobacter pylori, encodes type Ispecific and disease-associated virulence factors. Proc Natl Acad Sci USA 93, 14648-14653.

Chirgwin, J. M., Przybyla, A. E., MacDonald, R. J. \& Rutter, W. J. (1979). Isolation of biological active ribonucleic acid from sources enriched in ribonuclease. Biochemistry 18, 5294-5299.

Dhaenens, L., Szczebara, F. \& Husson, M. O. (1997). Identification, characterization, and immunogenicity of the lactoferrin-binding protein from Helicobacter pylori. Infect Immun 65, 514-518.

Doig, P. J., Austin, w. \& Trust , T. J. (1993). The Helicobacter pylori $19 \cdot 6$-kilodalton protein is an iron-containing protein resembling ferritin. J Bacteriol 175, 557-560.

Earhart, C. F. (1996). Uptake and metabolism of iron and molybdenum. In Escherichia coli and Salmonella typhimurium: Cellular and Molecular Biology, 2nd edn, vol. I, pp. 1075-1090. Edited by F.C. Neidhardt and others. Washington, DC: American Society for Microbiology.

Evans, D. J., Evans, D. G., Takemura, T., Nakano, H., Lampert, H. C. and Graham, D. Y. (1995a). Characterization of a Helicobacter pylori neutrophil-activating protein. Infect Immun 63, 2213-2220.

Evans, D. J., Evans, D. G., Lampert, H. C. \& Nakano, H. (1995b). Identification of four new prokaryotic bacterioferritins, from Helicobacter pylori, Anabaena variabilis, Bacillus subtilis and Treponema pallidum, by analysis of gene sequences. Gene 153, 123-127.

Forman, D. (1996). Helicobacter pylori and gastric cancer. Scand $J$ Gastroenterol 220, 23-26.

Frazier, B. A., Peifer, J. D., Russell, D. G., Falk, P., Olsen, A. N., Hammar, M., Westblom, T. U. \& Normark, S. J. (1993). Paracrystalline inclusions of a novel ferritin containing nonheme iron, produced by the human gastric pathogen Helicobacter pylori: evidence for a third class of ferritins. J Bacteriol 175, 966-972.

Genco, C. A. \& Desai, P. J. (1996). Iron acquisition in the pathogenic Neisseria. Trends Microbiol 4, 179-184.

Harrison, P. M. \& Arioso, P. (1996). The ferritins: molecular properties, iron storage function and cellular regulation. Biochim Biophys Acta 1275, 161-203.

Hempstead, P. D., Hudson, A. J., Artyniuk, P. J., Andrews, S. C., Banfield, M. J., Guest, J. R. \& Harrison, P. M. (1994). Direct observation of the iron-binding sites in a ferritin. FEBS Lett $\mathbf{3 5 0}$, 258-262.

Hughes, N. J., Kelly, D. J., Clayton, C. L. \& Chalk, P. A. (1997). Helicobacter pylori por $\mathrm{CDAB}$ and oor $\mathrm{DABC}$ genes encode distinct pyruvate: flavodoxin and 2-oxoglutarate : acceptor oxidoreductases which mediate electron transport to NADP. J Bacteriol 180, 1119-1128.

Husson, M. O., Legrand, D., Spik, G. \& Leclerc, H. (1993). Iron acquisition by Helicobacter pylori: importance of human lactoferrin. Infect Immun 61, 2694-2697. 
Izuhara, M., Takamune, K. \& Takata, R. (1991). Cloning and sequencing of an Escherichia coli gene which encodes a polypeptide having similarity to the human ferritin $\mathrm{H}$ subunit. Mol Gen Genet 225, 510-513.

Jiang, Q., Hiratsuka, K. \& Taylor, D. E. (1996). Variability of gene order in different Helicobacter pylori strains contributes to genome diversity. Mol Microbiol 20, 833-842.

Kahrs, A. F., Odenbreit, S., Schmitt, W., Heuermann, D., Meyer, T. F. \& Haas, R. (1995). An improved TnMax mini-transposon system suitable for sequencing, shuttle mutagenesis and gene fusions. Gene 167, 53-57.

Laemmli, U. K. (1970). Cleavage of structural proteins during the assembly of the head of the bacteriophage T4. Nature 227, 680-685.

Lee, A., Fox, J. \& Hazell, S. (1993). Pathogenicity of Helicobacter pylori: a perspective. Infect Immun 61, 1601-1610.

Litwin, C. M. \& Calderwood, S. B. (1993). Role of iron in regulation of virulence genes. Clin Microbiol Rev 6, 137-149.

Miller, J. H. (1972). Experiments in Molecular Genetics. Cold Spring Harbor, NY: Cold Spring Harbor Laboratory.

Miller, R. A. \& Britigan, B. E. (1997). Role of oxidants in microbial pathophysiology. Clin Microbiol Rev 10, 1-18.

Odenbreit, S., Till, M. \& Haas, R. (1996a). Optimized BlaMtransposon shuttle mutagenesis of Helicobacter pylori allows the identification of novel genetic loci involved in bacterial virulence. Mol Microbiol 20, 361-373.

Odenbreit, S., Wieland, B. \& Haas, R. (1996b). Cloning and genetic characterization of Helicobacter pylori catalase and construction of a catalase-deficient mutant strain. J Bacteriol 178, 6960-6967.

Pohlner, J., Krämer, J. \& Meyer, T. F. (1993). A plasmid system for high-level expression and in vitro processing of recombinant proteins. Gene 130, 121-126.

Sambrook, J., Fritsch, E. F. \& Maniatis, T. (1989). Molecular Cloning: a Laboratory Manual, 2nd edn. Cold Spring Harbor, NY: Cold Spring Harbor Laboratory.

Schaeffer, S., Hantke, K. \& Braun, V. (1985). Nucleotide sequence of the iron regulatory gene fur. Mol Gen Genet 200, 110-113.

Southern, E. M. (1975). Detection of specific sequences among DNA fragments separated by gel electrophoresis. J Mol Biol 98, 503.

Spiegelhalder, C., Gerstenecker, B., Kersten, A., Schiltz, E. \& Kist, M. (1993). Purification of Helicobacter pylori superoxide dismutase and cloning and sequencing of the gene. Infect Immun 61, 5315-5325.

Stojiljkovic, I., Bäumler, A. J. \& Hantke, K. (1994). Fur regulon in gram-negative bacteria: identification and characterization of new iron-regulated Escherichia coli genes by a fur titration assay. $J$ Mol Biol 236, 531-545.

Strobel, S., Bereswill, S., Allgaier, P., Balig, P., Sonntag, H.-G. \& Kist, M. (1998). Identification and analysis of a new vacA genotype variant of Helicobacter pylori in different patient groups in Germany. J Clin Microbiol 36, 1285-1289.

Taylor, D. E. (1996). Diversity among Helicobacter pylori isolates. J Clin Microbiol 34, 1041.

Tomb, J. F., White, O., Kerlavage, A. R. \& other authors (1997). The complete genome sequence of the gastric pathogen Helicobacter pylori. Nature 388, 539-547.

Touati, D., Jacques, M., Tardat, B., Bouchard, L. \& Despied, S. (1995). Lethal oxidative damage and mutagenesis are generated by iron in DELTA-fur mutants of Escherichia coli: protective role of superoxide dismutase. J Bacteriol 177, 2305-2314.

Velayudhan, J., Hughes, N. J., Andrews, S. C., Clayton, C. L. \& Kelly, D. J. (1997). Iron acquisition in Helicobacter pylori: characterization of $t b p \mathrm{~A}, f e c \mathrm{~A}$, and $e x b \mathrm{~B}$ homologues. Gut 41 (Suppl. 1), A109.

Wai, S. N., Takata, T., Takade, A., Hamasaki, N. \& Amako, K. (1995). Purification and characterization of ferritin from Campylobacter jejuni. Arch Microbiol 164, 1-6.

Wai, S. N., Nakayama, K., Umene, K., Moriya, T. \& Amako, K. (1996). Construction of a ferritin-deficient mutant of Campylobacter jejuni: contribution of ferritin to iron storage and protection against oxidative stress. Mol Microbiol 20, 1127-1134.

Wai, S. N., Nakayama, K., Takade, A. \& Amako, K. (1997). Overproduction of Campylobacter ferritin in Escherichia coli and induction of paracrystalline inclusions by ferrous compound. Microbiol Immunol 41, 461-467.

Worst, D. J., Otto, B. R. \& de Graaff, J. (1995). Iron-repressible outer membrane proteins of Helicobacter pylori involved in heme uptake. Infect Immun 63, 4161-4165.

Worst, D. J., Sparrius, M., Kuipers, E. J., Kusters, J. G. \& de Graaff, J. (1996). Human serum antibody response against iron-repressible outer membrane proteins of Helicobacter pylori. FEMS Microbiol Lett 144, 29-32.

Yariv, J., Kalb, A. J., Sperling, R., Bauminger, E. R., Cohen, S. G. \& Ofer, S. (1981). The composition and the structure of the bacterioferritin of Escherichia coli. Biochem J 197, 171-175.

Zimmermann, L., Angerer, A. \& Braun, V. (1989). Mechanistically novel iron-III transport system in Serratia marcescens. J Bacteriol $171,238-243$.

Received 1 April 1998; revised 20 May 1998; accepted 27 May 1998. 